\title{
PERCEPTIONS OF COVID-19 INFODEMIC AND CONSPIRACY THEORIES IN AFRICA: INSIGHT FROM BENIN CITY RESIDENTS IN NIGERIA
}

\author{
Emeke Precious Nwaoboli \\ Department of Mass Communication \\ University of Benin, Benin City, Edo State, Nigeria
}

\begin{abstract}
This study was an examination of the perceptions of COVID-19 infodemic and conspiracy theories in Africa: Insight from Benin City residents in Nigeria. The objectives of the study were to find out the perception of COVID19 infodemics and conspiracy theories in Africa; find out the various COVID-19 infodemics and conspiracy theories in Africa; and examine the level of dorminance of COVID-19 infodemics and conspiracy theories in Africa. The study population was 544, 499. Four hundred copies of questionnaire were distributed while 389 were retrieved and found usable. Findings from the study showed that there is still a huge dominance and acceptance of COVID-19 infodemics and conspiracy theories in Africa. The study therefore recommended that Africans should learn to always verify all COVID-19 information story they see and hear especially on social media as some of them are mere conspiracy theories and infodemics.
\end{abstract}

Keywords; COVID-19, Infodemic, conspiracy theories, Pandemic.

\section{INTRODUCTION}

SARS-COV2, the virus that causes COVID19, got its name from the virus's crown-like shape. The World Health Organization (WHO) (2019) declared in December 2019 that the official name of the 2019 new corona-virus is Coronavirus Disease, 2019 (COVID-19). According to Nwaoboli, Chukwu, Arijeniwa, and Asemah (2021), the Chinese Center for Disease Control and Prevention (China CDC) deployed a fast response team to Hubei province and Wuhan city to undertake epidemiological and etiological studies following the breakout of the disease and the rapid mortality of individuals who acquired it. Information overload is also known as an infodemic, which is a condition that leads to falsity, fake news, half-truths, conspiracies, and a variety of other types of information that have thrived on social media in recent years. Governments all around the world are increasingly concerned about the potentially hazardous nature of information sharing in the twenty-first century world propelled by digital technology. Despite the doom and gloom that the COVID-19 virus brought to the globe, progress was achieved with the development of vaccinations to assist combat the virus's effects and propagation. One of the many believable facts was achieved as a consequence of the inventiveness and teamwork that arose from the fact that the entire world was fighting the COVID-19 virus.

On the 27th of February 2020, Nigeria recorded its first case of Coronavirus when a 44-yearold Italian citizen was diagnosed with Covid-19 in Lagos State (Nwaoboli, Chukwu, Arijeniwa \& Asemah, 2021). Since the first verified case was reported in China in January 2020, this was the first case recorded in Nigeria. The World Health Organization (WHO) reported 172,821 confirmed cases of Covid-19 with 2,141 fatalities from January 3, 2020 to 6:30 p.m. on July 30, 2021, and a total of $3,938,945$ vaccine doses were given. Meanwhile, there were rumors that Covid-19 was not a Nigerian sickness, but rather a planned ploy by the ruling elite to steal money. Others questioned the veracity of Covid-19 on the ground, claiming that a disease like Covid-19 could not live in Nigerian soil. The mainstream media is likely to play an essential role in raising awareness about the Covid-19 epidemic. The media effort, which included talk shows, news broadcasts, magazine programs, features, and essays, were designed to raise awareness and educate the public about the symptoms, repercussions, and preventative techniques because there was no known medical cure at the time. This awareness was raised through the media, notably social media, radio, and 


\section{International Journal of Engineering Applied Sciences and Technology, 2021 \\ Vol. 6, Issue 5, ISSN No. 2455-2143, Pages 65-72 \\ Published Online September 2021 in IJEAST (http://www.ijeast.com)}

television. Nonetheless, there is a research gap in terms of the perspective Africans on COVID-19 infodemic and conspiracy theories. This study thus covers such research gaps by examining perceptions of COVID-19 infodemic and conspiracy theories in Africa while taking insights from Benin City residents in Nigeria

\section{Research Objectives}

The objectives of this study are to:

1. Find out the perceptions of COVID-19 infodemics and conspiracy theories in Africa

2. Find out the various COVID-19 infodemics and conspiracy theories in Africa

3. Examine the level of dorminance of COVID-19 infodemics and conspiracy theories in Africa

Understanding Infodemic and Conspiracy theories At a security meeting in Zurich, World Health Organization Director-General Tedros Adhanom Ghebreyesus coined the term "infodemic" (Department of Global Communications, 2020). Information overflow or excess, whether online or offline, is now referred to as an infodemic. The World Health Organization (WHO) defines an infodemic as "deliberate attempts to spread false information in order to weaken public health responses and advance alternative agendas of organizations or people". During the COVID-19 epidemic, for example, WHO complained about an oversupply of information, which led to the spread of disinformation across the virtual environment.

It is critical to emphasize that while having sufficient information about something to enable one to make an educated decision is a desirable thing, having too much of it can lead to poor decisionmaking (Davidoff, 2020). Davidoff goes on to say that an infodemic is a scenario in which someone has too much knowledge about something. Other terms for infodemic, according to Davidoff, include infobesity, information anxiety, infoxication, and information explosion. In today's world, when everyone has access to social media platforms, it's much easier to get information of various kinds, with the bulk of it proving to be incorrect. Fake news has been classified into a number of different categories. Fake news can include satire or parody, false connections, deceptive material, imposter content, altered content, and manufactured content, according to Ogbette et al (2019).

Fake news has dominated recent conversations in Nigeria, and it looks to be the most popular sort of information epidemic. It's possible that it's primarily due to the ethnic tensions that may be readily sparked by incorrect information. Furthermore, the nation is weak in terms of religion, since followers of the two main religionsChristianity and Islam-are sometimes readily persuaded by religious concerns, resulting in difficulties of division among Nigerians. One of the reasons contributing to increased ethnic and religious conflicts in Africa has been recognized as misinformation (AFP, 2020).

On the other hand, "conspiracy theories" are assertions of hidden schemes by two or more strong players to explain the ultimate causes of major social and political events and conditions (Aaronovitch, 2010; Byford, 2011). It is worth noting that conspiracy theorists do not necessarily agree that their theories are conspiracies, since some perceive the label as a method to discredit their claims. People spread conspiracy theories in a variety of ways, serving a variety of political, psychological, and societal goals. Conspiracy theories can be used as a rhetorical device to avoid unfavorable conclusions (Lewandowsky, Ecker, \& Cook, 2017).

Conspiracy theories are not usually based on actual erroneous ideas. They can be purposefully built or enhanced for strategic or political purposes (Lewandowsky, Ecker, \& Cook 2017). Conspiracy theories also have an impact on individuals as well as on society institutions. Their hazards (and advantages) are far-reaching, and much more research is needed to properly comprehend the significance of this widespread psychological, political, and social phenomena, particularly for the vulnerable and underprivileged populations who have been identified as the most likely to benefit (Douglas, Uscinski, Sutton, Cichocka, Nefes, Ang, \& Deravi, 2019).

\section{DORMINANT COVID-19 INFODEMICS AND CONSPIRACY THEORIES IN AFRICA}

\section{The fifth generation (5G) network is the cause of COVID-19}

Many individuals think that COVID-19 is caused by the 5G network, which has been extensively circulated on social media. Viruses are physiologically unable to transmit through the electromagnetic spectrum. Waves/photons are the latter, whereas biological particles made up of proteins and nucleic acids constitute the former. As a result, the emergence of $5 \mathrm{G}$ networks at the same time as COVID-19 is just coincidental and of course, 


\section{International Journal of Engineering Applied Sciences and Technology, 2021 \\ Vol. 6, Issue 5, ISSN No. 2455-2143, Pages 65-72 \\ Published Online September 2021 in IJEAST (http://www.ijeast.com)}

some parts of the world are already thinking of $6 \mathrm{G}$ networks. If $5 \mathrm{G}$ is the cause of COVID-19, what then will we be saying about $6 \mathrm{G}$ ? WHO (2020) adds to this by stating that viruses cannot travel through mobile networks and that COVID-19 is quickly spreading in several countries without $5 \mathrm{G}$ networks.

2. Bill Gate aims to reduce the World's population and control humans

The concept that COVID is part of a sinister Gatesled conspiracy to vaccinate the whole world's population is a current version of COVID-19 infodemic. Of course, there might be some truth in this; nevertheless, vaccinating a large portion of the world's population is Bill Gates' prediction to avert a death toll in the tens of millions and not to create additional fatalities. However, because the infodemic has spread so widely, Gates plans to utilize a vaccination program to implant digital microchips that will allow him to follow and control individuals.

\section{COVID-19 is a biological weapon}

COVID-19 was allegedly developed by Chinese scientists as a bio-warfare weapon, according to rumors. According to Pew Research, nearly three-inten Americans believe COVID-19 was created in a lab, either purposefully or unintentionally (the former is more popular: $23 \%$ believe it was created intentionally, while just $6 \%$ believe it was created by chance) (Mark, 2020).

\section{COVID-19 does not exist}

COVID-19, according to professional conspiracy theorists like David Icke and Alex Jones of InfoWars, does not exist, but is a globalist scheme to take away liberties (Mark, 2020). Early versions of this hypothesis, which claimed that the new coronavirus would be "no worse than flu," were popular on the political right, and subsequent versions are currently inspiring anti-lockdown rallies in numerous states throughout the US. Because believers are increasingly refusing to observe social distancing measures, they may be directly contributing to the spread of the pandemic in their communities and therefore increasing the fatality rate.

\section{COVID-19 VACCINE DEVELOPMENT, ROLL OUT AND PERCEPTIONS IN AFRICA}

Amidst the doom and gloom that the COVID-19 virus brought to the globe, progress was achieved with the development of vaccinations to assist combat the virus's effects and propagation. One of the many believable facts was achieved as a consequence of the inventiveness and teamwork that arose from the whole world was fighting the COVID19 virus. In Nigeria, to develop COVID-19 vaccine, Chief Afe Babalola (SAN), the founder of Afe Babalola University in Ado-Ekiti, Nigeria, requested that the federal government grant them permission to collaborate with scientists from Kenya and Japan to develop COVID-19 drugs and vaccines, but they were denied because the federal government was allegedly seen as frustrating private institutions' efforts to contribute to the development of the virus.

By politicizing arguments over the creation of the COVID-19 vaccine, opinion leaders tended to underuse the vaccination process. Even well-known politicians and policymakers had concerns about whether the virus was genuine, and others questioned the vaccine's sincerity of aim when it was initially developed. The COVID-19 vaccine was delivered to Nigeria via the COVID-19 vaccines worldwide access (COVAX) facility, which slid 3.94 million doses of the Astrazeneca/Oxford vaccine made by the Serum Institute of India from Mumbai to Abuja. First of all, the Nigeria Centre for Disease Control (NCDC) helped to develop a communication strategy to fight "infodemic in a pandemic, using diverse platforms and tools for communication and leveraging partnership (NCDC, 2021). Also, the need to vaccinate the health workers in the battle against the disease, deciding who comes next has sprung another debate.

South Africa is one of the first African countries to get the COVID-19 vaccination on February 1, 2021. AstraZeneca-SK Bioscience (AZSKBio) and the Serum Institute of India (AZ-SII) manufactured a million doses of the AstraZeneca/Oxford COVID-19 vaccine for India (Relief Web, 2021). Following the revelation of findings showing the vaccination had limited effectiveness against the 501Y.V2 variation of this coronavirus, the variant most frequent in the South African population, the roll-out of the AstraZeneca/Oxford COVID-19 vaccine was halted on February 8, 2021 (Heywood, 2021). South Africa began a roll-out of the Johnson \& Johnson COVID19 vaccine on February 17, 2021, with an initial 80,000 doses (Daily Maverick, 2021). In addition to being efficient against the 501Y.V2 variation, this vaccine is less expensive and requires just routine chilling for storage as compared to AstraZeneca/Oxford and other currently available vaccines. The country has received 9 million doses of the Johnson \& Johnson COVID-19 vaccine, with a further 20 million doses of the Pfizer/BioNTech vaccine due by the end of the first quarter.

On the 15th of February 2021, Zimbabwe got its first shipment of COVID-19 vaccine, with the 


\section{International Journal of Engineering Applied Sciences and Technology, 2021 \\ Vol. 6, Issue 5, ISSN No. 2455-2143, Pages 65-72 \\ Published Online September 2021 in IJEAST (http://www.ijeast.com)}

immunization campaign kicking out on the 18th of February 2021. (VoA News, 2021). The BBIBPCorV vaccine, developed by the Beijing Institute of Biological Products and Sinopharm, is now approved for use in Bahrain, China, Egypt, and the United Arab Emirates. The Chinese government donated 200,000 doses to Zimbabwe, with another 600,000 doses purchased by the Zimbabwean government and due to arrive in March 2021. Frontline workers, particularly medical staff, the elderly, and those with underlying illnesses, have had their dosages prioritized. The Indian government is expected to donate 75,000 doses of the COVID-19 vaccine to Zimbabwe. To attain herd immunity, the country planned to vaccinate at least 10 million of its 16 million citizens. Only 25,000 doses had been provided to healthcare and other frontline personnel as of 2 March 2021, two weeks following the immunization program's rollout (MoHCC, 2021). It should be noted that vaccine willingness varies significantly among the DR Congo's provinces, with Equateur reporting the lowest level of interest. Women and younger adults report having a weaker willingness to accept. Women tend to trust healthcare workers when it comes to trusted voices for a COVID-19 vaccination, thus doctors and nurses should be at the forefront of any engagement campaign. Senegalese respondents appear to be more likely to be exposed to and believe in disinformation than respondents from other nations evaluated in the study, according to Africa CDC (2021).

Among the 15 countries questioned, Ethiopians expressed the greatest willingness to adopt a new COVID-19 vaccination, with over 9-in$10(94 \%)$ saying they would accept it (Africa CDC, 2021). Regional disparities were noticeable, with the majority of people in Tigray (97\%) and Oromia (96\%) saying they would accept such a vaccine, while only 87 percent in Afar said they would. While the intention to vaccinate against COVID-19 is uniform across both genders, it differs by age group. Younger respondents reported not being willing to take a new COVID-19 vaccination throughout the 15 nations questioned, while the contrary is true in Ethiopia, where individuals under the age of 25 are much more receptive to receiving a COVID-19 vaccine than their older counterparts. More specifically, Gabon's reported readiness to adopt a new COVID-19 vaccination was found to be low; while, Kenya's stated willingness to take a COVID19 vaccine is high. Lack of trust and safety concerns are the most often claimed reasons for refusing to take a new vaccination by people who are opposed to it. Malawi's readiness to adopt a COVID-19 vaccination is quite high, according to Africa CDC
(2021), however a small but significant minority claim they would not. Women and individuals who reside in small towns are the most likely to decline a vaccination, while Moroccans are among the most anxious about safety problems surrounding new COVID-19 vaccines, despite a high level of faith in vaccines in general.

The findings of this study disagree with that of Africa CDC (2021), which found that in Nigeria, reported willingness to accept a COVID-19 vaccine was 76 percent, though it varied across variety of settings in the country, in line with the average respondent across 15 countries surveyed (79 percent). Africa CDC (2021) observed that younger respondents (those under the age of 24) are less enthusiastic about getting the vaccine than their elders and that this is consistent with the general pattern, which indicates that if a COVID-19 vaccine is deemed safe and effective, older people are more likely to receive it. When compared to those who know someone who has had COVID-19, those who don't know anybody who has had COVID-19 are less likely (76 percent) to be vaccinated (88 percent). Given that the vast majority of Nigerian respondents (95 percent vs. 80 percent overall) claim they are unaware of anybody who has tested positive for the virus, this might explain why two-thirds (67 percent) believe the threat from coronavirus is overstated.

Theoretical Framework

The Health Belief Model (HBM) and Theory of Reasoned Action served as the study's foundations. HBM was created in the early 1950s by US Public Health Service social scientists to better understand why individuals don't use disease preventive measures or screening tests for early illness diagnosis. It is one of the most commonly used models for explaining health behaviors, and it is used to explain and forecast individual changes in health behaviors. In terms of the current study, everyone would take the vaccination seriously if the sampled community views Covid-19 as a severe illness with the potential to produce major health consequences. However, if the community views the disease and vaccination as unimportant, unfavorable reactions are likely. This might explain why the Nigerian Center for Disease Control (NCDC) has continued to deliver conflicting messages about the virus's dangers, and why African countries are clamoring for their populations to get the COVID-19 vaccination.

The goal is to increase the virus's severity, which will motivate people to be vaccinated. In 1980, the Theory of Reasoned Action (TORA), also known as the Theory of Planned Behavior (TPB), became prominent. The theory's main goal is to anticipate a 


\section{International Journal of Engineering Applied Sciences and Technology, 2021 \\ Vol. 6, Issue 5, ISSN No. 2455-2143, Pages 65-72 \\ Published Online September 2021 in IJEAST (http://www.ijeast.com)}

person's intention to engage in a certain activity at a specific time and location. The selected norms are the consequence of a person's perceived control over their conduct, as well as their social and environmental circumstances. TPB claims that behavioral success is determined by both motive (intention) and ability (behavioral control), and it identifies three categories of beliefs: behavioral, normative, and control. Acceptance or approval from family, friends, and peers, for example, is likely to impact a person's development of a good attitude toward a behavior, boosting his or her desire to see the specific action through to completion. The importance of this theory to this study is that, similar to the COVID-19 vaccination, which purportedly boosts people's immune systems against the vaccine, the health Belief Model explains why and how individuals in Africa might carry out various reasoned behaviors and respond to COVID-19 vaccines.

\section{EMPIRICAL REVIEW}

Mass Media and Coronavirus Campaigns in Benin City: Examining the Status Conferral Approach was investigated by Nwaoboli, Arijeniwa, Chukwu, and Asemah (2021). The study's goals were to determine the extent to which Edo State residents were exposed to Coronavirus information in the media, X-ray Edo State residents' perceptions of Coronavirus as a result of the virus's conferral of status by the media, and determine the degree to which the media has conferred status on Coronavirus in Edo State. The survey was the research technique, and the questionnaire was the research instrument.

The findings of the study indicated that the media in Benin City have given COVID-19 a high status as a consequence of its regular coverage of the virus, but that despite the media's high esteem for the virus, some Benin City residents continue to doubt its authenticity. The results suggest that the media should ensure accurate statistical coverage of the corona virus, that more research should be done by other researchers, and that new theories capable of providing valid and reliable ways to supervise this type of public health emergency in the near and distant future should be proposed. The study also recommended that Edo State government should adopt more preventive measures with the media to avoid further spread of the virus.

In a cross-sectional retrospective research, Owusu, Sylverken, Ankrah, El-Duah, Ayisi-Boateng, Yeboah, et al. (2020) investigated the epidemiological profile of SARS-CoV-2 across selected areas in Ghana. The goal of the study was to describe the socio-demographic characteristics,
COVID-19 distribution pattern, and viral load dynamics among people living in Ghana's northern, middle, and southern belts. The sampling method was a cross-sectional retrospective research that looked at records of samples taken between February and July of 2020. Sputum, deep-cough saliva, and nasopharyngeal swabs were obtained from suspected COVID-19 patients in 12 Ghanaian areas for laboratory testing and confirmation using a real-time reverse transcription polymerase chain reaction (RTPCR). During the evaluation period, 72,434 samples were obtained, with the majority of the sampled people being females $(37,464 ; 51.9$ percent $)$. In the study population, 13.2 percent of people had SARSCoV-2 [95 percent confidence interval: 12.9, 13.4]. In comparison to females, males were more likely to be infected $(4,897 ; 51.5$ percent $)$. Individuals between the ages of 21 and 30 years old had the most infections $(3,144,33.4$ percent). Asymptomatic patients exhibited lower viral loads (49.9; IQR $=5.5-$ 3641.6) than symptomatic ones (1479.7 copies/l; IQR = 40.6-178919). There was a significant link between SARS-CoV-2 infection and gender or age (p0.05). Anosmia was the strongest predictor of SARS-CoV-2 infection among all suspected clinical manifestations (adj. OR (95 percent CI): 24.39). The average reproductive number was 1.36 , with a low of 1.28 and a high of 1.43 . The virus's reproductive number decreases over time, as seen by the virus's trajectory. The study also found that the epidemiological profile of COVID-19 cases in Ghana's northern, middle, and southern belts, with men and younger people being at higher risk of developing the disease. It was thus advised that health practitioners be aware of those who come with anosmia, as this was found to be the best predictor of viral infection.

Nwaoboli \& Asemah (2021) conducted another study on the use of fear appeals in the marketing of COVID-19 vaccine in Nigeria using chosen internet media (Premium Times and The Cable). The study's goals were to look at how online newspapers use fear appeals to promote COVID-19 vaccines, analyze the implications of Premium Times and The Cable's fear appeal news headlines in promoting COVID-19 vaccines, and look at the various veiled intentions of COVID-19 vaccine news headlines on Premium Times and The Cable. The Drive-Reduction Model served as the theoretical basis. Textual analysis was used as the research approach, while purposive sampling was used as the sampling strategy. The study's findings revealed that online newspapers use fear appeals in their coverage of COVID-19 vaccination stories, and that while the use of fear appeals may be intended to increase readership, such fear appeals have a significant 


\section{International Journal of Engineering Applied Sciences and Technology, 2021 \\ Vol. 6, Issue 5, ISSN No. 2455-2143, Pages 65-72 \\ Published Online September 2021 in IJEAST (http://www.ijeast.com)}

impact on the audience's decision to take the COVID19 vaccine or not. Fear appeals are too exploitative, therefore instead of using fear tactics in health communication initiatives, the media should use evidence-based and promising strategies like education-entertainment, humour, opinion leaders, and celebrity endorsements, according to the research. The study's conclusions were similar to those of the present one, but they were vastly different in breadth.

\section{METHODOLOGY}

The population of the study was the 544, 479 residents in Oredo, Ikpoba Okha and Egor Local Government Areas in Benin City, Edo State, Nigeria. The sample size of this study was determined by the Taro Yamane's sample size calculation propounded by Taro Yamanes (1967). The formular for the calculation is $n=N /\left[1+N(e)^{\wedge} 2\right]$, where $n$ is the sample size, $\mathrm{N}$ refers to the population of the study, E refers to the sampling error (usually 0.05 acceptable error), ${ }^{\wedge}$ means raised to power of, Therefore, $n=544,479$ $/\left[1+544,479(0.05)^{\wedge} 2\right]$, thus our sample size was 400 . The sampling technique was the multi-stage sampling research design. In the first stage, the researcher picked 3 most populated Local Government Areas within Benin metropolis, namely, Oredo Local Government Area, Ikpoba Okha Local Government Area and Egor Local Government Area. In the second stage, the researcher also randomly selected highly populated areas in the three local government areas. For Oredo, Ring road was selected, For Egor, Uselu was selected While for Ikpoba-Okah, Aduwawa was selected. In the third stage, the researcher chose simple random sampling technique to distribute 133 copies of questionnaire to residence of Oredo and Ikpoba-Okah respectively while the other 134 copies of questionnaire were randomly distributed in Ikpoba-Okhah Local Government Area. Furthermore, the research instrument was questionnaire while the simple random technique was adopted for the study. 400 copies of questionnaire were distributed while 389 were retrieved and found usable.

\section{Data Presentation, Analysis and Discussion}

Table 1

\begin{tabular}{|l|l|c|}
\hline \multicolumn{3}{|c|}{ 5G network is the cause of COVID-19 } \\
\hline Response & Frequency & Percentage \\
\hline Strongly & 145 & $37.3 \%$ \\
\hline
\end{tabular}

\begin{tabular}{|c|c|c|}
\hline agree & & \\
\hline Agree & 88 & $22.6 \%$ \\
\hline Neutral & 9 & $2.3 \%$ \\
\hline Disagree & 76 & $19.5 \%$ \\
\hline $\begin{array}{l}\text { Strongly } \\
\text { Disagree }\end{array}$ & 71 & $18.3 \%$ \\
\hline Total & 389 & 100 \\
\hline \multicolumn{3}{|c|}{$\begin{array}{l}\text { COVID-19 vaccines contain micro-chips } \\
\text { designed by Bill Gates to control humans }\end{array}$} \\
\hline $\begin{array}{l}\text { Strongly } \\
\text { agree }\end{array}$ & 90 & $23.1 \%$ \\
\hline Agree & 145 & $37.3 \%$ \\
\hline Neutral & 21 & $5.4 \%$ \\
\hline Disagree & 92 & $23.7 \%$ \\
\hline $\begin{array}{l}\text { Strongly } \\
\text { Disagree }\end{array}$ & 41 & $10.5 \%$ \\
\hline Total & 389 & 100 \\
\hline \multicolumn{3}{|c|}{ COVID-19 statistics are manipulated } \\
\hline $\begin{array}{l}\text { Strongly } \\
\text { agree }\end{array}$ & 97 & $24.9 \%$ \\
\hline Agree & 112 & $28.8 \%$ \\
\hline Neutral & 1 & $0.3 \%$ \\
\hline Disagree & 80 & $20.6 \%$ \\
\hline $\begin{array}{l}\text { Strongly } \\
\text { Disagree }\end{array}$ & 99 & $25.4 \%$ \\
\hline Total & 389 & $100 \%$ \\
\hline \multicolumn{3}{|c|}{$\begin{array}{c}\text { Vaccines for Africans are less safer than those } \\
\text { in western countries }\end{array}$} \\
\hline $\begin{array}{l}\text { Strongly } \\
\text { agree }\end{array}$ & 126 & $32.4 \%$ \\
\hline Agree & 93 & $23.9 \%$ \\
\hline Neutral & 9 & $2.3 \%$ \\
\hline Disagree & 88 & $22.6 \%$ \\
\hline $\begin{array}{l}\text { Strongly } \\
\text { Disagree }\end{array}$ & 73 & $18.8 \%$ \\
\hline Total & 389 & $100 \%$ \\
\hline \multicolumn{3}{|c|}{$\begin{array}{l}\text { COVID-19 is a biological weapon developed } \\
\text { in China to reduce the world's population } \\
\text { especially that of Africans }\end{array}$} \\
\hline $\begin{array}{l}\text { Strongly } \\
\text { agree }\end{array}$ & 180 & $46.3 \%$ \\
\hline Agree & 105 & $26.9 \%$ \\
\hline Neutral & 7 & $1.8 \%$ \\
\hline Disagree & 46 & $11.8 \%$ \\
\hline $\begin{array}{l}\text { Strongly } \\
\text { Disagree }\end{array}$ & 51 & $13.1 \%$ \\
\hline
\end{tabular}




\section{International Journal of Engineering Applied Sciences and Technology, 2021 \\ Vol. 6, Issue 5, ISSN No. 2455-2143, Pages 65-72 \\ Published Online September 2021 in IJEAST (http://www.ijeast.com)}

\begin{tabular}{|c|l|l|}
\hline Total & 389 & $100 \%$ \\
\hline
\end{tabular}

Source: Field Survey, 2021.

Data on the multivariate table 1 shows that there is still a large acceptance of infodemics and conspiracy theories among Nigerians and in extension, Africans. The data shows that majority of the people in Nigeria believe 5G network is the cause of COVID-19, COVID-19 vaccines contain micro-chips designed by Bill Gates to control humans; COVID-19 statistics are manipulated; vaccines for Africans are less safer than those in western countries; and that COVID-19 is a biological weapon developed in China to reduce the world's population especially that of Africans. The import of the above is that there is still a large acceptance of various conspiracy theories in Africa. This is perhaps as a result of the perception that the western world often wants to marginalize Africans and the poor belief in the efficacy, integrity and confidence in African leaders to objectively protect the human rights of Africans.

\section{CONCLUSION AND RECOMMENDATIONS}

In Africa, infodemics and conspiracy theories concerning COVID-19 still have a lot of clout. Most Africans are therefore affected by these infodemics and conspiracy theories, which prevent people from implementing COVID-19 preventive measures like as hand washing, wearing nasal masks, using hand sanitizers, and getting vaccinations. The mass media and the general people, both nationally and globally, must vigorously oppose these conspiracy theories and infodemics, which are far more than minor concepts. Conspiracy theories are formed for a number of causes, ranging from personality characteristics to the fulfillment of complicated social demands. Nevertheless, to curb the negative effects of infodemics and conspiracy theories:

1. Africans need to jettison the conspiracy theories and infodemics that COVID-19 vaccine contains micro-chips and is a biological weapon to reduce the population $f$ Africa as such theories have no foundation nor empiricism

2. Africans should learn to always verify all COVID-19 information they see and hear especially on social media as some of them are mere conspiracy theories and infodemics

3. Relevant authorities such as the government, law court, health centres, etc should make and implement policies to penalize anyone who peddles COVID-19 infodemics and conspiracy theories. This would help promote objectivity in information dissemination abut COVID-19 in Africa

Byford, J. (2011). Conspiracy theories: A critical introduction. Basingstoke, United Kingdom: Palgrave MacMillan.

Byford, J. (2011). Conspiracy theories: A critical introduction. Basingstoke, United Kingdom: Palgrave MacMillan.

Byford, J. (2011). Conspiracy theories: A critical introduction. Basingstoke, United Kingdom: Palgrave MacMillan.

\section{REFERENCES}

Aaronovitch, D. (2010). Voodoo histories: The role of the conspiracy theory in shaping modern history. New York, NY.

AFP. (2019, April 14). 'Fake news' driving ethnoreligious crisis in Nigeria. Retrieved from https://www.france24.com/en/20190414nigeria-buhari-fake-news-azikwe-islammuslim-christianity.

Africa CDC (February, 2021). COVID-19 Vaccine Perceptions: A 15-country study. Retrieved from

file:///C:/Users/user/Downloads/COVID19\%20Perception\%20Survey\%20Final\%20 Report\%2020.02.2021.pdf

Byford, J. (2011). Conspiracy theories: A critical introduction. Basingstoke, United Kingdom: Palgrave MacMillan.

Davidoff, T. Q. (2020). Dealing with an epidemic of information in the midst of a pandemic. The Journal of Urgent Care Medicine. Retrieved from https://www.jucm.com/dealing-with-anepidemic-of-information-in-the-midst-of-apandemic/.

Daily Maverick (2021). South Africa to Give First COVID-19 Vaccine Doses to President, Health Workers. Available online: https://www.dailymaverick.co.za/a rticle/2021-02-17-south-africa-to-givefirst-covid-19-vaccine-doses-to-presidenthealth-workers/.

Douglas, K., Uscinski, J., Sutton, R., Cichocka, A., $\quad$ Nefes, T., Ang, C. S., and Deravi, F. (2019). Understanding Conspiracy Theories. Political Psychology. 40(1), 3-35.

Heywood, M. (2021) South Africa Faces Serious Setback in its AstraZeneca Vaccination Campaign - Government Turns to Plan B. Available online: https://www.dailymaverick.co.za/a 


\section{International Journal of Engineering Applied Sciences and Technology, 2021 \\ Vol. 6, Issue 5, ISSN No. 2455-2143, Pages 65-72 \\ Published Online September 2021 in IJEAST (http://www.ijeast.com)}

rticle/2021-02-07-south-africa-faces-

serious-setback-in-its-astrazeneca-

vaccination-campaign-government-turns-

to-plan-b/.

Lewandowsky, S., Ecker, U. K. and Cook, J. (2017). Beyond misinformation: Understanding and coping with the "post-truth" era. Journal of Applied Research in Memory and Cognition, 6(4), 53-369.

Lynas, M. (2020). COVID: Top 10 current conspiracy theories. Retrieved from https://allianceforscience.cornell.edu/ blog/2020/04/covid-top-10-currentconspiracy-theories/

MoHCC. (2021). Zimbabwe COVID-19 SitRep. 2021.Available online: http://www.mohcc.gov.zw/index.p hp?option=com_phocadownload\&view=c ategory\&id=13\&Itemid $=744$.

Nigerian Centre for Disease Control NCDC. (2021). Covid-19 in Nigeria. Retrieved from http://www.covid-19.ncdc.gov.ng/.

Nwaoboli, E. P., and Asemah, E. S. (2021). Textual Analysis of Select Online Media Use of Fear Appeals in the Promotion of COVID-19 Vaccination in Nigeria. In E. S. Asemah (Ed.). (pp. 1-10).

Nwaoboli, E. P., Chukwu, N. Arijeniwa, F. A. and Asemah, E. S (2021). Mass Media and Coronavirus Campaigns in Benin City: Examining the Status Conferral Approach. In Osemeke, M., Ohiokha, F., Oaikhena, M., Ola, K., Okwudiri, E. (Eds.) (pp. 223-232).

Ogbette, A. S., Idam, M. O., Kareem, A. O. and Ogbette, D. N. (2019). Fake news in Nigeria: Causes, effects and management. Information and Knowledge Management, 9(2), 96-99.

Owusu, M., Sylverken AA, Ankrah ST, El-Duah P, A yisi-Boateng NK, Yeboah R, et al. (2020) Epidemiological profile of SARS-CoV-2 among selected regions in Ghana: A crosssectional retrospective study. PLoS ONE 15(12), e0243711.

Paul A, Sikdar D, Mahanta J, Ghosh S, Jabed MA, Paul., S, et al. (2021) Peoples' understanding, acceptance, and perceived challenges of vaccination against COVID-19: A cross- sectional study in Bangladesh. PLoS ONE 16(8), $\mathrm{e} 0256493$.

Relief Web (2021). COVAX Expects to Start Sending Millions of COVID-19 Vaccines to Africa in February. Available online: https://reliefweb.int/report/world/c ovax-expects-start-sending-millionscovid-19-vaccines-africa-february

VoA News (2021) Zimbabwe Rolls Out Coronavirus Vaccination Program. 2021. Available online: https://www.voanews.com/covid19-pandemic/zimbabwe-rolls-outcoronavirus-vaccination-program. 